\title{
Kontrol Odağı ve İşyeri Prokrastinasyonu Arasındaki İlişkinin İncelenmesi: Tekstil Sektöründe Bir Araştırma
}

\author{
Tuğçe KUMRAL ${ }^{1}$ Mahmut PAKSOY ${ }^{2}$ Serdar BOZKURT ${ }^{3}$ \\ $\ddot{O}_{z}$
}

Bu çalışmanın temel amacl; çalışanların içsel veya dışsal kontrol odaklı olmalarıyla işyeri prokrastinasyonu (erteleme alışkanlığ ) arasında anlamlı bir ilişkinin olup olmadığının tespit edilmesidir. Bu çerçevede, İstanbul'da tekstil sektöründe faaliyet gösteren alt işletmedeki beyaz ve mavi yakal çalışanlara yönelik bir araş̧ırma gerçekleştirilmiştir. Çalı̧̧ma sonucunda, kontrol odağı ile işyeri prokrastinasyonu arasında bir iliş̧ki belirlenmiş̧tir. Dlşsal kontrol odağ olanlarda, daha fazla işyeri prokrastinasyonu gözlemlenmişstir. Kontrol odağının, işyeri prokrastinasyonu boyutlarından oyalanma davranışının farklıllklaştı̆̆ belirlenirken, siber kaytarma davranışı ile herhangi bir farklllık tespit edilememiştir. Ayrlca, işyeri prokrastinasyonu ve boyutları ile demografik özelliklerden; cinsiyet, eğitim durumu, kıdem ve medeni durum ile farklilıklar ortaya konulmuştur.

Anahtar Kelimeler: Kontrol Odă̆g, İsyeri Prokrastinasyonu (Erteleme Alışkanlı̆̆l)

JEL Sinıflandırma Kodları: M10, M19

\section{Investigation of The Relationship Between Locus of Control and Workplace Procrastination: A Research In The Textile Sector}

\begin{abstract}
The main purpose of this study; to determine whether there is a meaningful relationship between employees' internal locus of control or external locus of control and workplace procrastination. In this framework, a survey was conducted on white and blue-collar employees in six companies operating in the textile sector in Istanbul. As a result of the research; there is a significant relationship between locus of control and workplace procrastination. More workplace procrastination has been observed in those externally controlled. While there was a difference between the locus of control and soldiering behavior from workplace procrastination dimensions, there was no difference with the cyberslacking behavior. In addition, there are differences between workplace procrastination and its dimensions with demographic characteristics; gender, educational status, seniority and marital status.
\end{abstract}

Keywords: Locus of Control, Workplace Procrastination

JEL Classification Codes: M10, M19

\footnotetext{
${ }^{1}$ Arş. Grv., İstanbul Kültür Üniversitesi, İktisadi ve İdari Bilimler Fakültesi, İşletme Bölümü, t.kumral@iku.edu.tr

2 Prof. Dr., İstanbul Kültür Üniversitesi, İktisadi ve İdari Bilimler Fakültesi, İşletme Bölümü, m.paksoy@iku.edu.tr

3 Doç. Dr., Yıldız Teknik Üniversitesi, İktisadi ve İdari Bilimler Fakültesi, İşletme Bölümü, Örgütsel Davranış Anabilim Dalı, sbozkurt@yildiz.edu.tr
} 


\section{T. KUMRAL - M. PAKSOY - S. BOZKURT}

\section{GİRIŞ}

Günümüz iş dünyasının en önemli sorunların başında çalışanların verimsiz olduğu düşüncesi bulunmaktadır. $\mathrm{Bu}$ sorunun altında yatan temel faktörlerinden birinin, çalışanların işyeri prokrastinasyonu olduğu düşünülmektedir. Araştırmalar, çalışanların çalışma saatleri boyunca kişisel aktivitelerde ortalama 1,5 ila 3 saat harcadığını bildirmektedir. Diğer tahminlere göre; iş günlerinde internette harcanan zamanın \%30 ila \%65'i iş ile ilgili değildir ve bu, yalnızca ABD'de y1lda 85 milyar dolara kadar çıkabilen \%30-40 verimlilik kaybına yol açmaktadır. (Metin vd., 2016: 255). Ayrıca, işyeri prokrastinasyonu kavramının ne tip kişisel özelliklerden etkilendiğinin de araştırılması önem arz etmektedir. Nitekim bir çalışmada yetişkin bireylerin \%25'i işyeri prokrastinasyonu alışkanlıklarının kişisel özelliklerinden kaynaklandığını düşünmektedirler (Nguyen vd., 2013: 388). Bu çerçevede, çalışanların işyeri prokrastinasyonunun hem bireysel hem de örgütsel verimliliği etkilediği düşünülmektedir. Verimliliğin artırılması örgütler açısından en önemli sorunlarından biri olduğu için, bu problemi etkileyebilecek çalıșan davranışlarının incelenmesi ve buna sebep olan faktörleri açığa çıkarmak yararlı olabilecektir. Çalışanların işyeri prokrastinasyonunu etkileyen içsel (örneğin; kendi çabalarının sonuçlarının yetersiz olduğunu düşünmeleri) ve dışsal (örneğin; başarısızlığın nedeninin tamamen şans olduğu) çevresel faktörler ile çalışanların işyeri prokrastinasyonu arasında ilişki var mıdır? şeklindeki sorunsal bu çalışmanın temel amacı olarak görülmektedir.

\section{KURAMSAL ÇERÇEVE}

\subsection{Kontrol Odağı Kavramı}

Kontrol odağ kavramı sosyal öğrenme kuramından yola çıkılarak geliştirilmiş bir kavramdır. Bandura tarafindan ortaya konulan sosyal öğrenme kuramı, bireylerin öğrenmelerinde çevrenin etkisinin olduğunu ifade etmektedir. Bu doğrultuda bireylerin deneme yanılma yoluyla öğrenebilecekleri görülmektedir (Çelen, 1999: 114). Bu kuram bağlamında şekillenen kavramlardan biri de kontrol odağıdır. Kontrol odağı 
kavramından ilk olarak bahseden isim 1950'li yıllarda Julian B. Rotter olmuştur. Kontrol odağı; bireylerin tecrübe ettikleri başarı veya başarısızlıklarını neye atfettikleri ile ilgilidir (Rotter, 1966: 2). Kontrol odaklılık, içsel ve dışsal kontrol odağı olarak ikiye ayrılmaktadır. İçsel kontrol odağına sahip olanlar, işle ilgili elde ettikleri sonuçların ve başarılarının kendi çaba ve yeteneklerine dayandığına inanmaktadırlar. Dişsal kontrol odağına sahip olanlar ise, işle ilgili elde ettikleri sonuçların ve başarılarının diğer bireyler veya dış faktörlerden dolayı meydana geldiğine inanmaktadırlar (Spector, 1988: 35). Şans, kader ve çevre dış faktörlere örnek olarak gösterilebilir.

İçsel kontrol odağı olan bireyler tepkilerini dile getirmeye ve prososyal davranış sergilemeye daha eğilimli olmakta ve olumsuz davranışlardan kaçınmaktadırlar (HoffiHofstetter ve Mannheim, 1999: 667). Ayrıca içsel kontrol odağı daha yüksek olan bireyler, davranışlarının farklılık oluşturduğuna inanmaktadırlar. Bu nedenle inisiyatif kullanarak kendileri için belirlenenlerden daha fazla işe yönelik olarak ve iş tanımlarının ötesinde davranış göstermeye yatkın olmaktadırlar (Withey ve Cooper, 1989: 525). Bu bireyler, çevrelerinde gerçekleşen olayları kendi davranışlarıyla değiştirebileceklerine inanmaktadırlar. Başarılı veya başarısız olmak, çevre koşullarını değiştirmek için çaba sarf etmek onlar için önem taşımaktadır (Özler vd., 2017: 738). Dışsal kontrol odağına sahip bireyler ise; kendilerine uygun davranışın ne olduğu konusunda karar verebilmek için başkalarının davranışlarına bakmakta; içsel kontrol odağına sahip bireyler uygun davranışın ne olduğuna kendileri karar vermektedirler (Forte, 2005: 65). Dışsal kontrol odağına sahip bireyler yaşadıkları olayların kendi dışındaki çevresel faktörlere bağlı olduklarına düşündüklerinden dolayı belirlenen amaçlara erişebilmek için herhangi bir gayret gösterme eğiliminde bulunmamaktadırlar (Özler vd., 2017: 738). İçsel kontrol odağına sahip bireylerin dışsal kontrol odaklılara kıyasla olaylarla başa çıkma konusunda daha yetenekli oldukları ve bu konudaki motivasyonlarının oldukça fazla olduğu belirlenmiştir. Ayrıca bu bireyler daha fazla 


\section{T. KUMRAL - M. PAKSOY - S. BOZKURT}

risk alma eğilimine bağlı olarak girişimci, başarı odaklı, cesaretli ve otonom özelliklere sahip olduğu belirlenmiştir (Meydan ve Basım, 2015: 101).

\section{2. İşyeri Prokrastinasyonu Kavramı}

Çalışanlarda sıklıkla gözlemlenebilen davranışlardan biri de işyeri prokrastinasyonudur. Çoğu motivasyon teorisi, motivasyonun bireysel performans1 ve iş tatminini nasıl artırdığını ve bireylerin olumlu sonuçlara nasıl ulaşabileceklerini açıklamaya çalışmaktadır. Nadiren, insanların neden bir şey yapmadıkları konusuna odaklanılır. Prokrastinasyon, insanların bir şey yapmamaya nasıl motive edildiklerini gösteren bir örnek olarak düşünülebilir. Bu kavram, bireyin bir niyeti uygulamaktan kaçınması ve geciktirmesi olarak tanımlanabilir (Eerde, 2000: 372). Prokrastinasyon kelimesi Latinceden türetilmiştir ve -pro ileriye anlamına gelirken, -kras yarın anlamına gelmektedir (Gupta vd., 2012: 196). İşyeri prokrastinasyonu genellikle; erteleyerek veya geciktirerek görevleri yerine getirme ya da karar verme konusundan kaçınma gibi bir özellik ya da davranışsal eğilim olarak ifade edilmektedir (Milgram ve Tenne, 2000: 141). Kaçınma, daha keyifli aktiviteler veya düşünceler ile dikkatin dağılması olarak nitelendirilebilir. Aynı zamanda işyeri prokrastinasyonu; bilinçli bir zarar verme niyeti içermeyen, bir tür üretkenlik karşıtı davranış olarak tanımlanabilir. (Metin vd., 2016: 255).

Teorik çerçeve açısından, üç ana boyutun prokrastinasyonu etkilediği ortaya konmuştur. Bu üç ana boyut, içsel faktörler, durumsal faktörler ve görev özellikleridir. Birinci boyut açısından, kişinin bireysel özelliklerinin, işyeri prokrastinasyonunu etkilediği düşünülmektedir. Durumsal faktörler boyutunda ise, örneğin bir çalışan hastalık veya aile sorunu nedeniyle, görevini zamanında yerine getiremeyebilir. İşyerinde prokrastinasyona yol açan üçüncü bir faktör ise, çalışanların başarısız oldukları veya açı uçlu son teslim tarihlerine sahip oldukları görevlerle karşı karşıya kaldıkları zamandır (Gupta vd., 2012: 197). 
Çalışma ortamında işyeri prokrastinasyonu ile ilişkili olan davranışlar, araştırmacılar tarafindan farklı biçimlerde kategorize edilmiştir. İşyeri prokrastinasyonu bir çalışmada; akademik, davranışsal, kararsal ve zorunlu olmak üzere dört farklı kategori altında toplamıştır. Özellikle kararsal işyeri prokrastinasyonu, örgütler açısından çok önemlidir. Kararsal işyeri prokrastinasyonu, bireylerin belirli bir süre içerisinde karar verememeleri veya karar verme yeteneklerinin olmaması olarak kabul edilmektedir (Milgram ve Tenne, 2000: 141). Başka bir çalışmada ise işyeri prokrastinasyonu; oyalanma ve siber kaytarma olmak üzere iki boyutta ele alınmıştır. Oyalanma; başkalarına zarar vermeyi veya işleri çalışma arkadaşları üzerine yıkmayı amaçlamadan, günde bir saatten fazla olacak şekilde, iş ile ilgili görevlerden kaçınma olarak tanımlanmıştır. Oyalanmaya örnek olarak; uzun kahve molaları almak, dedikodu yapmak, çıktı miktarını azaltmak gösterilebilir. İkinci erteleme biçimi olan siber kaytarma ise, işyerlerinde teknolojinin geniş çaplı kullanılmasıyla ortaya çıkmıştır (Metin vd., 2016: 255). Bu erteleme biçimine yönelik davranışlar, web sitelerinde dolaşma ve işle ilgili olmayan kişisel e-postaları okuma vb. şeklindedir ve zamanın verimsiz kullanılmasına neden olduğu ve çalışanların işteki taleplerini yerine getirmesine engel olduğu için işletmeler ve yöneticiler açısından endişe kaynağı olarak görülmektedir (Lim, ve Chen, 2012: 343). Bu tip ertelemede çalışanlar bilgisayarlarında işlerini yapıyor gibi bir izlenim verirken; aslında internet üzerinden alışveriş yapabilir, sosyal paylaşım sitelerini kullanabilir veya oyun oynayabilirler. Araştırmalar, şirketlerin siber kaytarma nedeniyle verimlilik kayıpları, hukuki yaptırımlar vb. büyük zararlara katlandıklarını ortaya koymuştur (Metin vd., 2016: 255). Garrett ve Danziger (2008) tarafından yapılan bir araştırmaya göre, yüksek statüye sahip, iyi eğitimli ve yüksek gelir elde eden çalışanlarda daha yüksek siber kaytarmanın gözlemlendiği belirlenmiştir (Garrett ve Danziger, 2008: 287). 


\section{ARASTTIRMANIN METODOLOJISI}

\subsection{Araştırmanın Amacı ve Önemi}

$\mathrm{Bu}$ çalışmanın temel amacı, çalışanların içsel ve dışsal kontrol odaklı olmaları ile işyeri prokrastinasyonu arasındaki ilişkiyi incelemektir. $\mathrm{Bu}$ doğrultuda, araştırmanın sorunsalı "Çalışanların içsel veya dışsal kontrol odaklı olmaları ile işyeri prokrastinasyonu (erteleme alışkanlığı) arasında anlamlı bir ilişki var mıdır?" şeklindedir. Böylelikle temel rekabet avantajı kaynağı olarak görülen çalışanların sahip oldukları odaklar belirlenebilecektir. Bu doğrultuda bireyleri erteleme davranışına yönlendirebilecek temel faktörler ortaya konulmaya çalışılmıştır. Çalışanların erteleme davranışına neden olan faktörlerin belirlenmesi ve buna yönelik tedbirlerin alınmasına yönelik önerilerin ortaya konulabilmesi çalışmanın önemini artırmaktadır. Ayrıca çalışma sonuçları, ülkemizde benzeri çok fazla çalışma yapılmamış olması nedeniyle de önemlidir.

\subsection{Araştırmanın Kapsamı}

Araştırmanın evrenini, İstanbul ilinde Bağcılar ilçesindeki tekstil imalat sektöründe faaliyet gösteren altı işletmenin beyaz ve mavi yakalı çalışanları oluşturmaktadır. Veriler kolayda örnekleme yöntemi ile toplanmıştır. Toplamda 450 çalışanı bulunan altı işletmede, mesai saatlerinin uygunluğu doğrultusunda 300 çalışana anket dağıtılabilmiştir. Gönderilen anketlerden 220'si geri dönmüş, sadece 178 tanesi analize uygun bulunmuştur. $\mathrm{Bu}$ ise yaklaşık olarak \%40'l1k bir orandır.

\subsection{Veri Toplama Aracı}

Araştırmada veri toplama aracı olarak anket kullanılmıştır. Anket formunda iki adet ölçekten oluşmaktadır. İlk ölçek, Rotter (1966) tarafından geliştirilmiştir. Bu ölçeğin Türkçe geçerlilik ve güvenilirlik çalışması Dağ (1991) tarafından “İç-Dış Kontrol Odağı Ölçeği (RIDKOÖ)", adıyla yapılmıştır. İkinci ölçek ise, Metin, Taris ve Peeters (2015) tarafından geliştirilmiş, “İşyerinde Erteleme Davranışı Ölçeği (İEDÖ)’’dir. İç- 
dış kontrol ölçeği 29 ifade ile işyerinde erteleme davranışı ölçeği ise 12 ifadeden oluşmaktadır. İç-dış kontrol odağı ölçeğinde yer alan ifadeler, iki seçenekli yargı cümlelerinden oluşan bir yapı içermekte ve çalışanların bunlardan bir tanesini tercih etmesi istenmektedir. Ölçekteki altı ifade dolgu ifadesidir ve puanlanmamaktadır. 23 madde ise, içsel ve dişsal kontrole ait tercihli ifadelerden oluşmaktadır. Bireyin yüksek puanlar alması dışsal kontrol odağını ifade etmektedir. İşyerinde erteleme davranışı ölçeğinde 7'li Likert tipi ölçüm aracı kullanılmıştır. Bu ölçekte $0=$ "Hiç", 6= "Her zaman" şeklinde ifade edilmektedir.

\subsection{Araştırma Hipotezlerinin Geliştirilmesi}

Kontrol odaklılık, çalışanların erteleme alışkanlığını etkileyen temel bireysel faktörlerden biridir. Erteleme alışkanlığı olmayan bireylerin, erteleme alışkanlığı olanlara göre daha fazla içsel kontrol odağına sahip oldukları görülmektedir. İçsel kontrol odaklılar genellikle işleri gerçekleştirme eğilimindedirler (Lonergan ve Maher, 2000: 216). Bu doğrultuda içsel ve dişsal kontrol odaklı olma ile erteleme davranışı arasında ilişki olduğu düşünülmektedir. Bu doğrultuda oluşturulan araştırma modeli (Şekil 1) ve hipotezler şu şekildedir:

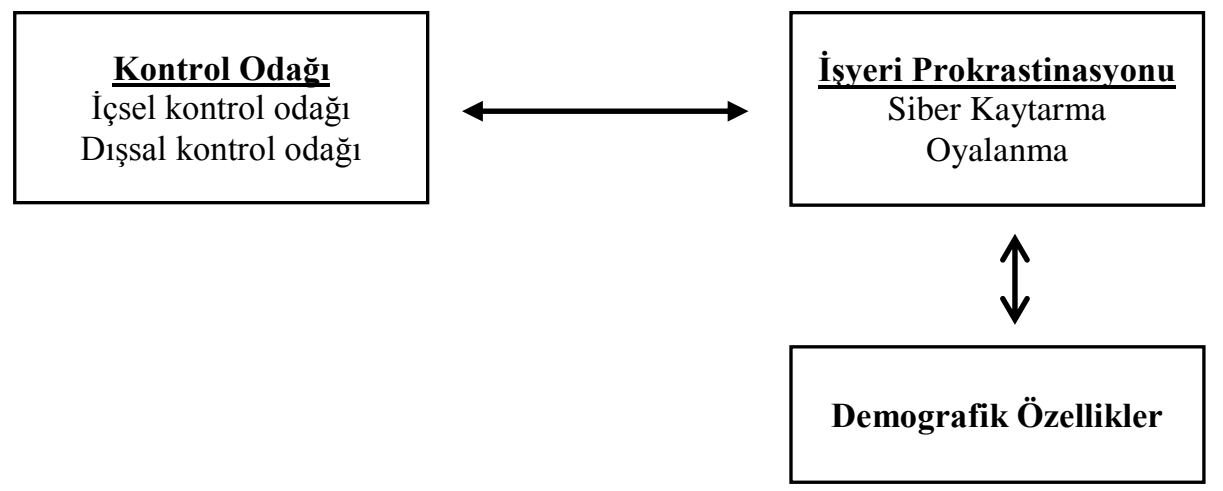

Şekil 1. Araştırma Modeli

Hipotez 1: Kontrol odağına göre, işyeri prokrastinasyonu farklılık göstermektedir. 


\section{T. KUMRAL - M. PAKSOY - S. BOZKURT}

Hipotez 2: Demografik değişkenlere göre, işyeri prokrastinasyonu farklllık göstermektedir.

\subsection{Bulgular ve Yorumlar}

Araştırma katılımcılarının demografik özellikleri incelendiğinde; katılımcıların 109'unun kadın (\%61) ve 69'unun erkek (\%39), katılımcıların 18-25 yaş arası 22 kişi (\%12), 26-35 yaş arası 80 kişi (\%45), 36-45 yaş arası 67 kişi (\%38) ve 46-55 yaş arası 9 kişi (\%5) olduğu görülmektedir. Çalışanların ortalama çalışma yılı 5,48 yıl (ss=5,36) yıl olarak hesaplanmıştır. Katılımcıların 128'i (\%72)'si evli, 50'si ise (\%28) bekar olduğu belirlenmiştir. Çalışanların pozisyonu incelendiğinde; 13’ünün (\%7) yönetici ve 165 'inin ise çalışan (\%93) olduğu belirlenmiştir. Yine katılımcıların eğitim durumu incelendiğinde; ilköğretim mezunu 59 kişi (\%33), lise 91 kişi (\%51) ve yüksekokul ve üzeri mezuniyete sahip 28 kişi (\%16) olarak belirlenmiştir. İşyeri prokrastinasyonu ölçeğinin güvenilirliğine ilişkin Cronbach Alpha değeri 0.915 olarak hesaplanmıştır. $\mathrm{Bu}$ değerin sosyal bilimler açısından oldukça güvenilir olduğu görülmektedir (Kayış, 2005). Kontrol odağ için ise Kuder-Richardson-21 formülü ile hesaplanmış ve 0,561 olarak belirlenmiştir. Bu değer de yüksek olmasa da kabul edilebilir sınırlar içerisinde yer almaktadır (Özdamar, 2016).

Araştırmadaki ölçekler ve boyutlarına ilişkin tanımlayıcı istatistiki analiz sonuçları incelendiğinde; kontrol odağına ait ortalama=1,58 (ss: ,49), işyeri prokrastinasyonu için ortalama=1,20 (ss: 1,07), işyeri prokrastinasyonunun alt boyutlarından oyalanma davranışı için ortalama=1,20 (ss: 1,06) ve siber kaytarma için ortalama=1,20 (ss: 1,36) olarak hesaplanmıştır. Çalışanın kontrol odağındaki eğilimleri daha çok dışsal kontrol odaklılık yönündedir. Katılımcıların işyeri prokrastinasyonu ve boyutları için değerlendirmeleri ise "nadiren" ile "ara sıra" seçenekleri arasında yer almaktadır (Tablo 1). 
Tablo 1. Tanımlayıcı İstatistikler

\begin{tabular}{|l|c|c|}
\hline Değişkenler & $\overline{\mathbf{x}}$ & ss \\
\hline Kontrol odağı & 1,58 &, 49 \\
\hline İşyeri prokrastinasyonu & 1,20 & 1,07 \\
\hline Oyalanma davranış1 & 1,20 & 1,06 \\
\hline Siber kaytarma davranış1 & 1,20 & 1,36 \\
\hline
\end{tabular}

$\mathrm{N}=178$

Araştırmadaki değişkenlerin arasındaki ilişkilerin tespit edilmesi amacıyla korelasyon analizinden yararlanılmıştır. Çalışanları kontrol odağı ile işyeri prokrastinasyonu arasında pozitif yönde düşük düzeyde ilişki olduğu görülmektedir. İşyeri prokrastinasyonu boyutlarına ilişkin durum incelendiğinde oyalanma davranışı ile kontrol odağı arasında ilişki tespit edilirken, siber kaytarma davranışları ile (p:0.073<0.05) herhangi bir ilişki olmadığı belirlenmiştir. Bu durumda çalışanların dışsal kontrol odaklılık puanlarının artışı, işyeri prokrastinasyonu göstermelerini artırdığg düşünülmektedir (Tablo 2).

Tablo 2. Korelasyon Analizi

\begin{tabular}{|l|c|c|c|c|}
\hline Değişkenler & 1 & 2 & 3 & 4 \\
\hline Kontrol odağ1 (1) & 1 & & & \\
\hline İsyeri prokrastinasyonu (2) &, $220^{* *}$ & 1 & & \\
&, 003 & & & \\
\hline Oyalanma (3) &, $248^{* *}$ &, $954^{* *}$ & 1 & \\
&, 001 &, 000 & & \\
\hline Siber kaytarma (4) &, 135 &, $883^{* *}$ &, $700^{* *}$ & 1 \\
&, 073 &, 000 &, 000 & \\
\hline
\end{tabular}

$\mathrm{N}=178, * * \mathrm{p}<0.01$ 


\section{T. KUMRAL - M. PAKSOY - S. BOZKURT}

Yukarıdaki tespiti daha net ortaya koyabilmek ve araştırma hipotezini test etmek için bağımsız iki örnek t-testi yapılmıştır. Diğer bir deyişle kontrol odaklılık türüne göre, işyeri prokrastinasyonu ve boyutları farklılık göstermekte midir? sorunsalına yanıt aranmiştır.

Tablo 3’ten görüleceği üzere, kontrol odağ1 türüne göre işyeri prokrastinasyonu gösterme arasında istatistiksel olarak anlamlı bir farklılık bulunmuştur. $\mathrm{Bu}$ farkın yönünü tespit için tanımlayıcı istatistik sonuçları incelendiğinde; içsel kontrol odağına sahip bireylerde erteleme davranışı "nadiren" şeklindeki seçeneğe yakınken, dışsal kontrol odağına sahip çalışanlarda ise "ara sıra" şeklindeki seçeneğe yakın olarak belirlenmiştir. Ayrıca işyeri prokrastinasyonu boyutlarından oyalanma davranışı ile kontrol odağı arasında istatistiksel olarak anlamlı bir farklılık bulunmuştur. Bu farkın yönünü tespit için tanımlayıcı istatistik sonuçları incelendiğinde erteleme davranışına benzer sonuçlar çıktığı görülmektedir. Ancak siber kaytarma davranışı ile kontrol odağı arasında istatistiksel olarak anlamlı bir farklılık bulunamamıştır (Tablo 3).

Tablo 3. Bağımsız İki Örnek t-testi Sonuçları

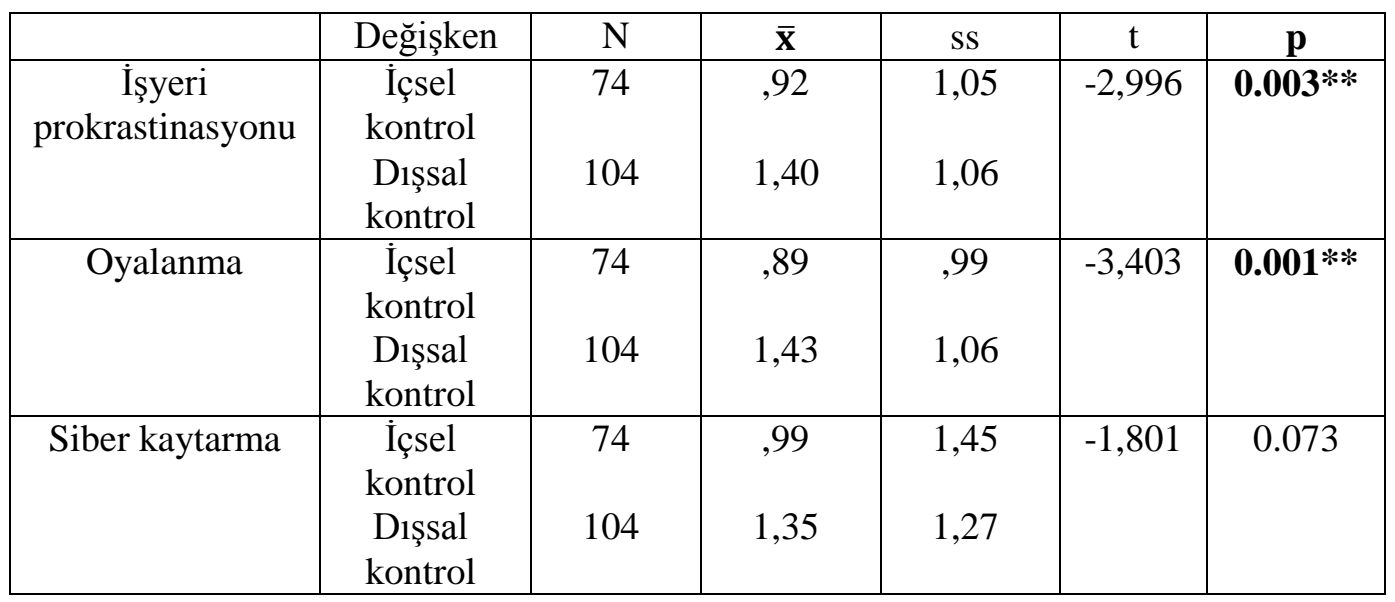

$* * \mathrm{p}<0.01$

Demografik değişkenlerden cinsiyete göre, çalışanların işyeri prokrastinasyonu ve boyutları farklı1ık göstermektedir şeklindeki hipotez için t-testinden yararlanılmıştır. 
Cinsiyet değişkenine göre, işyeri prokrastinasyonu ve boyutları farklılık göstermektedir. $\mathrm{Bu}$ farkın yönü için tanımlayıcı istatistik sonuçları incelendiğinde; erkek çalışanların işyeri prokrastinasyonunun daha yüksek olduğu görülmektedir. $\mathrm{Bu}$ sonuca göre, erkek çalışanların kadınlara nazaran daha yüksek kaytarma davranışı algısının olduğu söylenebilir (Tablo 4).

Tablo 4. Bağımsız İki Örnek t-testi Sonuçları

\begin{tabular}{|c|c|c|c|c|c|c|}
\hline & Özellik & $\mathrm{N}$ & $\overline{\mathbf{x}}$ & $\mathrm{ss}$ & $\mathrm{t}$ & $\mathrm{p}$ \\
\hline \multirow{2}{*}{$\begin{array}{c}\text { İşyeri } \\
\text { prokrastinasyonu }\end{array}$} & Kadın & 109 &, 88 &, 96 & $-5,351$ & $\mathbf{0 . 0 0 0}$ *** \\
& Erkek & 69 & 1,71 & 1,07 & & \\
\hline Oyalanma & Kadın & 109 &, 94 &, 97 & $-4,234$ & $\mathbf{0 . 0 0 0}$ *** \\
& Erkek & 69 & 1,61 & 1,90 & & \\
\hline Siber kaytarma & Kadın & 109 &, 76 & 1,11 & $-5,673$ & $\mathbf{0 . 0 0 0 * * *}$ \\
& Erkek & 69 & 1,91 & 1,44 & & \\
\hline
\end{tabular}

$* * * \mathbf{p}<0.001$

Demografik değişkenlerden "eğitim durumuna göre, çalışanların işyeri prokrastinasyonu ve boyutları farklılık göstermektedir" şeklindeki hipotez için tek yönlü varyans analizinden yararlanılmıştır. Analiz sonucunda sadece oyalanma davranışı boyutunda farklılık ortaya çıkmıştır. Bu farkın yönünü bulmak için yapılan post-hoc testlerinden Tukey testi sonucunda, ilköğretim ve yüksekokul/üniversite mezunları arasında farklılıklar olduğu görülmüştür. İlköğretim mezunları için ortalama=1,02 (ss:0,95) ve yüksekokul/üniversite mezunları için ise ortalama=0,95 (ss:0,93) olarak hesaplanmıştır. Eğitim seviyesi yükseldikçe oyalanma davranışının azaldığı söylenebilir (Tablo 5). 
Tablo 5. ANOVA Tablosu - Eğitim Durumu

\begin{tabular}{|c|c|c|c|c|c|c|}
\hline \multicolumn{2}{|c|}{} & $\begin{array}{c}\text { Kareler } \\
\text { toplamı }\end{array}$ & df & Ort. kare & F & p \\
\hline prokrastinasyonu & Gruplar arası & 4,286 & 2 & 2,143 & 1,859 &, 159 \\
& Gruplar içi & 201,699 & 175 & 1,153 & & \\
& Toplam & 205,985 & 177 & & & \\
\hline Oyalanma & Gruplar arası & 7,016 & 2 & 3,508 & 3,170 &, $\mathbf{0 4 4} *$ \\
& Gruplar içi & 193,637 & 175 & 1,106 & & \\
& Toplam & 200,653 & 177 & & & \\
\hline Siber kaytarma & Gruplar arası & 2,212 & 2 & 1,106 &, 590 &, 555 \\
& Gruplar içi & 327,968 & 175 & 1,874 & & \\
& Toplam & 330,180 & 177 & & & \\
& & & & & \\
\hline
\end{tabular}

$* \mathbf{p}<0.05$

Demografik değişkenlerden kıdeme göre, çalışanların işyeri prokrastinasyonu ve boyutları farkl11ık göstermektedir şeklindeki hipotez için tek yönlü varyans analizinden yararlanılmıştır. Analiz sonucunda, işyeri prokrastinasyonu ve oyalanma davranışı boyutunda farklılık ortaya çıkmıştır. Farkın yönünü bulmak için yapılan post-hoc testlerinden Tukey testi sonucunda, bu farkın 3 yıldan az (ort:0,94) ve 4-6 y1l aras1 kıdeme sahip çalışanlarla (ort:1,06), 10 yıll ve üzeri çalışanlar (ort:1,84) arasında olduğu görülmüştür. Kıdem arttıkça işyeri prokrastinasyonu ve oyalanma davranışının arttı̆̆ söylenebilir (Tablo 6). 
Tablo 6. ANOVA Tablosu - Kidem

\begin{tabular}{|c|c|c|c|c|c|c|}
\hline & & $\begin{array}{l}\text { Kareler } \\
\text { toplam1 }\end{array}$ & $\mathrm{df}$ & Ort. kare & $F$ & $\mathrm{p}$ \\
\hline $\begin{array}{c}\text { İşyeri } \\
\text { prokrastinasyonu }\end{array}$ & $\begin{array}{l}\text { Gruplar } \\
\text { aras1 }\end{array}$ & 18,865 & 3 & 6,288 & 5,737 & ,001** \\
\hline & Gruplar içi & 180,871 & 165 & 1,096 & & \\
\hline & Toplam & 199,736 & 168 & & & \\
\hline Oyalanma & $\begin{array}{c}\text { Gruplar } \\
\text { aras1 }\end{array}$ & 25,349 & 3 & 8,450 & 8,329 &, $000 * *$ \\
\hline & Gruplar içi & 167,383 & 165 & 1,014 & & \\
\hline & Toplam & 192,732 & 168 & & & \\
\hline Siber kaytarma & $\begin{array}{l}\text { Gruplar } \\
\text { aras1 }\end{array}$ & 8,880 & 3 & 2,960 & 1,558 & ,202 \\
\hline & Gruplar içi & 313,527 & 165 & 1,900 & & \\
\hline & Toplam & 322,408 & 168 & & & \\
\hline
\end{tabular}

$* * \mathbf{p}<0.01$

Demografik değişkenlerden "medeni duruma göre, çalışanların işyeri prokrastinasyonu ve boyutları farklılı göstermektedir" şeklindeki hipotez için ttestinden yararlanılmıştır. Analiz sonucunda, işyeri prokrastinasyonu ve oyalanma davranışı boyutunda farklılık ortaya çıkmıştır. Tanımlayıcı istatistiki analizler incelendiğinde, işyeri prokrastinasyonu evliler için ortalama=1,08 ve bekar çalışanlar için ortalama=1,51 olarak hesaplanmıştır. Oyalanma davranışı için ise evliler için ortalama $=1,07$ ve bekar çalışanlar için ortalama=1,54 olarak belirlenmiştir. Ancak siber kaytarma için herhangi bir farklılık gözlenmemiştir. İşyeri prokrastinasyonu ve oyalanma davranışının evli çalışanlara göre bekar çalışanlarda daha fazla olduğu söylenebilir (Tablo 7). 
Tablo 7. Bağımsız İki Örnek t-testi Sonuçları

\begin{tabular}{|c|c|c|c|c|c|c|}
\hline & Özellik & $\mathrm{N}$ & $\overline{\mathbf{x}}$ & $\mathrm{ss}$ & $\mathrm{t}$ & $\mathrm{p}$ \\
\hline İşyeri & Evli & 128 & 1,08 & 1,04 & $-2,390$ & $\mathbf{0 , 0 1 8}$ \\
& Bekar & 50 & 1,51 & 1,13 & & \\
\hline Oyalanma & Evli & 128 & 1,07 &, 98 & $-2,451$ & $\mathbf{0 , 0 1 7}$ \\
& Bekar & 50 & 1,54 & 1,19 & & \\
\hline Siber kaytarma & Evli & 128 & 1,11 & 1,38 & $-1,509$ & 0,133 \\
& Bekar & 50 & 1,45 & 1,31 & & \\
\hline
\end{tabular}

*p $<\mathbf{0 . 0 5}$

\section{SONUÇ VE ÖNERILER}

$\mathrm{Bu}$ çalışmada, bireylerin içsel veya dışsal kontrol odaklı olmalarıyla işyeri prokrastinasyonu arasında anlamlı bir ilişkinin olup olmadığı irdelenmiş̧tir. Üzerinde durulan bir diğer konu işyeri prokrastinasyonu ve boyutlarının demografik özellikler bakımından farklılık gösterip göstermediği olmuştur. Çalışma sonucunda; kontrol odağı ile işyeri prokrastinasyonu arasında bir ilişsi belirlenmiştir. Dışsal kontrol odağına sahip olanların, daha fazla işyeri prokrastinasyonu davranışı gösterdikleri ortaya konmuştur. Çalışanların kontrol odağına göre işyeri prokrastinasyonu boyutlarından oyalanma davranışının farklılık gösterdiği tespit edilirken, siber kaytarma davranışında ise böyle bir farklılığa rastlanmamıştır. Bunun nedeni, örneklemin tekstil sektöründen olmasından ve çalsşanların masa başında çok fazla zaman geçirmemelerinden kaynaklı olabilir. İşyeri prokrastinasyonu ve boyutları ile demografik özellikler; cinsiyet, eğitim durumu, kıdem ve medeni durum arasında istatistiksel olarak farkl11ıklar belirlenmiştir.

$\mathrm{Bu}$ çerçevede örgütler, çalışanlarına geri bildirim sağlayarak ve onlara işlerinin değerini anımsatarak işyeri prokrastinasyonunu azaltabilirler. İçsel kontrol odağı yüksek olan diğer bir deyişle kontrolü elinde tuttuğunu hisseden çalışanların yüksek 
başarı elde edecekleri düşünülebilir. Bu nedenle, çalışanların dışsal odaklılıktan içsel odaklılığa yönlendirebilecek insan kaynakları uygulamaları önemli olabilecektir.

Çalışmada bazı kısıtlar bulunmaktadır. Örneklemin sadece tekstil sektöründe çalışanlar oluşması ve İstanbul ili ile sınırlı olması önemli kısıtlardandır. Aynı değişkenler farklı ölçeklerle veya sektör ve il bazında karşılaştırmalı olarak tekrar yapılabilir. Ayrıca gelecek çalışmalarda, işyeri prokrastinasyonuna neden olan diğer bireysel ve durumsal faktörler ve bunların etkileşimleri araştırılabilir. Bu kavram, iş tatmini, örgütsel bağl1lık, beş faktör kişilik özellikleri gibi değişkenler ile birlikte ele alınabilir.

\section{KAYNAKÇA}

ÇELEN, N. (1999), Öğrenme Psikolojisi, Ankara: İmge Kitabevi.

EERDE, W. V. (2000), "Procrastination: Self-regulation in Initiating Aversive Goals", Applied Psychology, 49, 372-389.

FORTE, A. (2005), "Locus of Control and the Moral Reasoning of Managers", Journal of Business Ethics, 58, 65-77.

GARRETT, J.N., KELLY, R. (2008). “On Cyberslacking: Workplace Status and Personal Internet Use at Work", CYBERPSYCHOLOGY \& BEHAVIOR, 11 (3), 287292

GUPTA, R., HERSHEY D. A., GAUR J. (2012), "Time Perspective and Procrastination in the Workplace: An Empirical Investigation", Current Psychology, 31, 195-211.

HOFFI-HOFSTETTER, H., MANNHEIM B. (1999), “'Managers' Coping Resources, Perceived Organizational Patterns, and Responses During Organizational Recovery From Decline', Journal of Organizational Behavior, 20, 665-685. 
KAYIŞ, A. (2005), Güvenirlik analizi, Şeref Kalaycı (Ed.) içinde, SPSS uygulamalı Çok Değişkenli İstatistik Teknikleri (ss. 404-409). Ankara: Asil Yayın Dağıtım.

LIM, V. K., CHEN, D. J. (2012), "Cyberloafing at the workplace: gain or drain on work?', Behaviour \& Information Technology, 31(4), 343-353.

METIN, U. B., TARIS T. W., PEETERS M. C. W. (2016), "Measuring Procrastination at Work and Its Associated Workplace Aspects', Personality and Individual Differences, 101, 254-263.

MEYDAN, C. H., BASIM H. N. (2015), “Örgütsel Vatandaşlık Davranışında Kontrol Odağı, Örgütsel Adalet Algıs1 ve Örgütsel Bağl1lığın Etkisi’, Anadolu Üniversitesi Sosyal Bilimler Dergisi, 15(1), 99-116.

MILGRAM, N., TENNE R. (2000), “Personality Correlates of Decisional and Task Avoidant Procrastination", European Journal of Personality, 14, 141-156.

NGUYEN, B., STEEL P., FERRARI J. R. (2013), "Procrastination's Impact in the Workplace and the Workplace's Impact on Procrastination', International Journal of Selection and Assessment, 21, 388-399.

ÖZDAMAR, K. (2016), Ölçek ve Test Geliştirme Yapısal Eşitlik Modellemesi, Eskişehir: Nisan Kitabevi.

ÖZLER, E., GIDERLER C., BARAN H. (2017), “Öz Yeterlilik ve Kontrol Odağının Bireylerin Girişimcilik Niyeti Üzerindeki Etkisini Belirlemeye Yönelik Bir Araştırma', Uluslararası Yönetim İktisat ve İşletme Dergisi, 736-747.

ROTTER, J. B. (1966), "Generalized Expectancies for İnternal Versus External Control of Reinforcement', Psychological Monographs, 80, 1-28.

SPECTOR, P. E. (1988), “Development of the Work Locus of Control Scale”, Journal of Occupational Psychology, 61, 335-340. 
Dokuz Eylül Üniversitesi İktisadi ve İdari Bilimler Fakültesi Dergisi Cilt:33, Sayl:2, Yll:2018, ss.499-515

WITHEY, M. J., COOPER W. H. (1989), "Predicting Exit, Voice, Loyalty, and Neglect”, Administrative Science Quarterly, 34, 521-539. 